\title{
Isolation and Chemical Characterization of Plasma Membranes from the Yeast and Mycelial Forms of Candida albicans
}

\author{
By M. S. MAR RIOTT \\ Department of Biochemistry, The University, Cambridge CB2 I $Q W$
}

(Received 24 June 1974; revised 30 August 1974)

SUMMARY

It has been possible to induce the yeast-mycelium transformation in Candida albicans by growth of the organism under completely defined conditions in batch culture. Protoplasts have been obtained from the two forms by using a lytic enzyme preparation from Streptomyces violaceus. A plasma membrane fraction was prepared by osmotic lysis of these protoplasts and fractionated by using a combination of differential and discontinuous sucrose density-gradient flotation centrifugation. The purity of this fraction was determined by radioactive dansylation and iodination of plasma membranes of intact protoplasts followed by localization of the radioactivity upon fractionation. This procedure demonstrated less than $4 \%$ contamination of the plasma membrane fraction with other cell membranes. Chemical analysis of this fraction revealed that the major components were protein and lipid. Membranes from the yeast form contained (w/w): $50 \%$ protein, $45 \%$ lipid, $9 \%$ carbohydrate and $0.3 \%$ nucleic acid. Plasma membranes from the mycelial form contained significantly more carbohydrate and were found to be composed of (w/w): $43 \%$ protein, $31 \%$ lipid, $25 \%$ carbohydrate and $0.5 \%$ nucleic acid. Marked differences were also observed between the phospholipid, free and esterified sterols, and total fatty acids of membranes from the two forms of the organism.

\section{INTRODUCTION}

The yeast-mycelium transformation in Candida albicans occurs under a variety of conditions and has been shown to be dependent on the nature of the carbon and energy source (Nickerson \& Mankowski, I953), the glucose/phosphate ratio(Widra, 1964), the incubation temperature (Chattaway, Holmes \& Barlow, 1968 ), the $\mathrm{CO}_{2}: \mathrm{O}_{2}$ ratio in the culture system (Mardon, Balish \& Phillips, 1969), and the nitrogen source (Mardon, Hurst \& Balish, 1971). The media used in these studies were not always defined, but if any significant conclusions are to be made concerning the mechanism(s) controlling cell morphology and division in dimorphic fungi such as $C$. albicans it is necessary to work under defined conditions. Hence, completely synthetic media have been used throughout our investigation.

Following the original work of Boulton \& Eddy (1962), numerous workers have attempted to isolate plasma membranes from a variety of yeasts. Three techniques have been used: enzymic removal of wall and subsequent osmotic lysis of protoplasts, followed by differential and/or density-gradient centrifugation (Garcia-Mendoza \& Villaneuva, 1967; Longley, Rose \& Knights, 1968; Schibeci, Rattray \& Kidby, I973a); sonic or mechanical disruption of whole cells and separation of the cell envelope from other cellular components by centrifugation, followed by digestion of the wall to leave the plasma membrane (Nurminen, Oura \& Suomalainen, 1970; Dubé, Setterfield, Kiss \& Lusena, 1973); and mechanical disruption of whole cells, followed by fractionation using differential and density-gradient centrifugation (Matile, Moor \& Mühlethaler, 1967). 
The diversity of methods used to isolate plasma membranes and criteria used for assessing purity renders it impossible to compare data from different laboratories. One of the most successful methods employed to locate and assess the purity of the plasma membrane preparation has involved radioactive labelling of intact protoplasts and observation of the distribution of radioactivity upon subsequent fractionation (Schibeci et al. 1973a). Again, however, a wide range of enzymes is available for the production of protoplasts (e.g. the digestion juices of Helix pomatia, lytic enzymes $\mathrm{L}_{1}$ from Cytophaga, lytic enzymes from Streptomyces spp. and exo- $\beta$-I,3-glucanases from Basidiomycetes QM806), and these may influence the structure and composition of the plasma membrane preparation.

Candida albicans is an opportunistic pathogen causing both mild and severe infections, the latter under conditions in which the patient's immuno-response system has been impaired (e.g. following the administration of immuno-suppressant drugs after organtransplant surgery). It is also a dimorphic fungus, and both forms are found in clinical lesions. However, it is the mycelial form which is generally believed to be the invasive form of the organism. Clinically, the most important antibiotics used in the treatment of fungal infections are the polyenes. These are membrane-active antibiotics which complex with sterols in the plasma membrane of susceptible organisms, thus affecting membrane permeability and allowing vital cytoplasmic components to leak out (Lampen, Arnow, Borowska \& Laskin, 1962). The selective action of polyenes, therefore, lies in their differing affinities for sterols in the fungal plasma membrane as opposed to the host's cell membranes. Hence, any differences in the sterol content of the plasma membranes of the yeast and mycelial forms may be of importance from a chemotherapeutic point of view. More recently, however, work by Bittman \& Fischkoff (1972) and Drabikowski, Lagwinska \& Sarzala (1973) suggests that sterol/phospholipid and sterol/protein interactions in natural membranes may play an important role in determining an organism's sensitivity to polyenes. Since a complete understanding of the mode of action of polyenes will require a knowledge of the nature of the fungal plasma membrane, this study on the isolation and characterization of this component from $C$. albicans was undertaken.

\section{METHODS}

Strains and culture media. Candida albicans strain 6406, obtained from the Mycological Reference Laboratory, Public Health Laboratory Service, was used. The yeast form was grown at $37^{\circ} \mathrm{C}$ in an orbital incubator in a medium (GSV medium) modified from that of Mardon et al. (1969) (Table I). Growth was determined by extinction and dry-weight measurements. The mycelial form was induced by static incubation at $37^{\circ} \mathrm{C}$ in a medium (SSV medium) similar to that of Nickerson \& Mankowski (I953), modified in the light of work by Widra (1964) (Table I). Growth was determined by dry-weight measurements.

Streptomyces violaceus 3196 was obtained from Professor J. R. Villanueva (Department of Microbiology, Salamanca University).

Protoplast formation. The three enzyme preparations used were: snail gut juice (KochLight, Colnbrook, Buckinghamshire); lytic enzymes $\mathrm{L}_{1}$ from Cytophaga (BDH); 'Strepzymes' prepared from Streptomyces violaceus 3196 by the method of Elorza, Munoz-Ruiz \& Villanueva (1966). Candida albicans was harvested in the mid-exponential phase of growth, corresponding to a suspension density of 0.2 to $0.3 \mathrm{mg}$ dry $\mathrm{wt} / \mathrm{ml}$, and resuspended at a density of $10 \mathrm{mg} / \mathrm{ml}$ in $0.1 \mathrm{M}$-ammonium bicarbonate containing $0.01 \mathrm{M}$-mercaptoethanol. After $30 \mathrm{~min}$ at $23{ }^{\circ} \mathrm{C}$ the cells were harvested and suspended at $5 \mathrm{mg} / \mathrm{ml}$ in $0 \cdot \mathrm{I} \mathrm{M}$-phosphate buffer pH 6.8, containing $0.6 \mathrm{M}$-potassium chloride (final concentration) as osmotic stabilizer. The snail digestive juices were used as described by Kobayashi, Friedman \& Kofroth (1964), 
Table I. Growth media used for induction of the yeast and mycelial forms

$\begin{array}{lcc}\text { Component } & \begin{array}{c}\text { Yeast medium (GSV) } \\ (\mathrm{g} / \mathrm{l})\end{array} & \begin{array}{c}\text { Mycelial medium (SSV) } \\ (\mathrm{g} / \mathrm{l})\end{array} \\ \text { Glucose } & 25.00 & \mathrm{I} \cdot 00 \\ \mathrm{Starch} & - & \mathrm{I} \cdot 00 \\ \left(\mathrm{NH}_{4}\right)_{2} \mathrm{SO}_{4} & 2 \cdot 50 & 2.50 \\ \mathrm{KH}_{2} \mathrm{PO}_{4} & 3.00 & 1.25 \\ \mathrm{~K}_{2} \mathrm{HPO}_{4} & 0.05 & - \\ \mathrm{CaCl}_{2} & 0 \cdot 10 & 0 \cdot 10 \\ \mathrm{MgSO}_{4} \cdot 7 \mathrm{H}_{2} \mathrm{O} & 0.50 & 0.05 \\ \mathrm{MgCl}_{2} .6 \mathrm{H}_{2} \mathrm{O} & 2 \cdot 00 & 0.16 \\ \text { Vitamin solution* } & 10 \mathrm{ml} / \mathrm{l} & 10 \mathrm{ml} / \mathrm{l}\end{array}$

$*$ Vitamin solution (per $100 \mathrm{ml}$ ): $0.01 \mathrm{mg}$ biotin; $2.00 \mathrm{mg}$ each of calcium pantothenate, pyridoxin, nicotinic
acid and thiamin $\mathrm{HCl} ; 10.00 \mathrm{mg}$ meso-inositol.

the Cytophaga enzymes according to the method of Baird \& Cunningham (I97I) and the 'strepzymes' according to the method of Garcia-Mendoza \& Villanueva (1962).

Characterization of protoplasts. Regeneration. Protoplasts from the yeast form were counted by using a haemocytometer slide and diluted to known cell densities with either sterile distilled water or sterile, molten $8 \%(\mathrm{w} / \mathrm{v})$ gelatin, containing $0.6 \mathrm{M}$-potassium chloride, at $37^{\circ} \mathrm{C}$. Samples were spread over nutrient agar (Oxoid) plates and incubated at $37^{\circ} \mathrm{C}$ to determine the percentage of cells capable of regeneration.

Fluorescent labelling. Whole yeasts and protoplasts were incubated for $15 \mathrm{~min}$ at $23{ }^{\circ} \mathrm{C}$ in either $0.1 \%$ Tinopal BOPT (Ciba-Geigy Ltd, Manchester) or 0.0 I \% fluorescein-conjugated Concanavalin A (fl-Con A), prepared according to the method of Tkacz, Cybulska \& Lampen (197I), and observed with a Leitz Ortholux u.v. microscope.

Plasma membrane preparation. Protoplasts were harvested by centrifugation and lysed by resuspension in $\mathrm{O} \cdot \mathrm{I} \mathrm{M}$-tris- $\mathrm{HCl}$ buffer $\mathrm{pH} 7 \cdot 2$, containing $0.0 \mathrm{I} \mathbf{M}-\mathrm{Mg}^{2+}$ ions. The membrane fraction was collected by centrifugation at $5000 \mathrm{~g}$ for $\mathrm{I} 5 \mathrm{~min}$. The pellet was resuspended in $50 \%(\mathrm{w} / \mathrm{v})$ sucrose, made up in the same buffer, and $5 \mathrm{ml}$ samples were placed in $7.5 \times 2.2 \mathrm{~cm}$ cellulose nitrate centrifuge tubes. Continuous sucrose gradients $(50-20 \%$ w/v) were then prepared on top of these 'cushions' and the tubes centrifuged to equilibrium ( 18 to $24 \mathrm{~h}$ ) at $82500 \mathrm{~g}$ (av.) in a Beckman L2 65B ultracentrifuge with an SW 27 rotor. Bands were detected after centrifugation by pumping the gradients through a Cary I 5 recording spectrophotometer and measuring the $E_{280}$ (Fig. I $a$ ). By using these data, a discontinuous sucrose density gradient was designed for subsequent fractionation of membranes from both the yeast and mycelial form (Fig. $\mathrm{I} b$ ).

Radioactive labelling. The two procedures described below have been used to label plasma membranes from other cells and organisms (Kasai, Podleski \& Changeux, 1970; Salton, Schor \& $\mathrm{Ng}$, 1972). Dansyl chloride is a nucleophilic reagent and dansylation of protein is thus favoured by alkaline conditions. However, it is rapidly hydrolysed in aqueous solutions and needs to be dissolved in acetone. The addition of acetone to a suspension of protoplasts, even in small amounts, caused a certain degree of lysis. Thus, when the labelled protoplasts were harvested, it was necessary to use low-speed centrifugation $(600 \mathrm{~g})$ to separate the remaining intact protoplasts from lysed material. The specificity of the reagent in labelling the plasma membrane and not the intracellular membranes probably depends on the difference in $\mathrm{pH}$ values between the suspending buffer and the cell cytoplasm, since the plasma membrane is permeable to dansyl chloride (Bretscher, $1973 b$ ).

(i) Dansyl chloride. Protoplasts were suspended at a density equivalent to $20 \mathrm{mg}$ whole- 


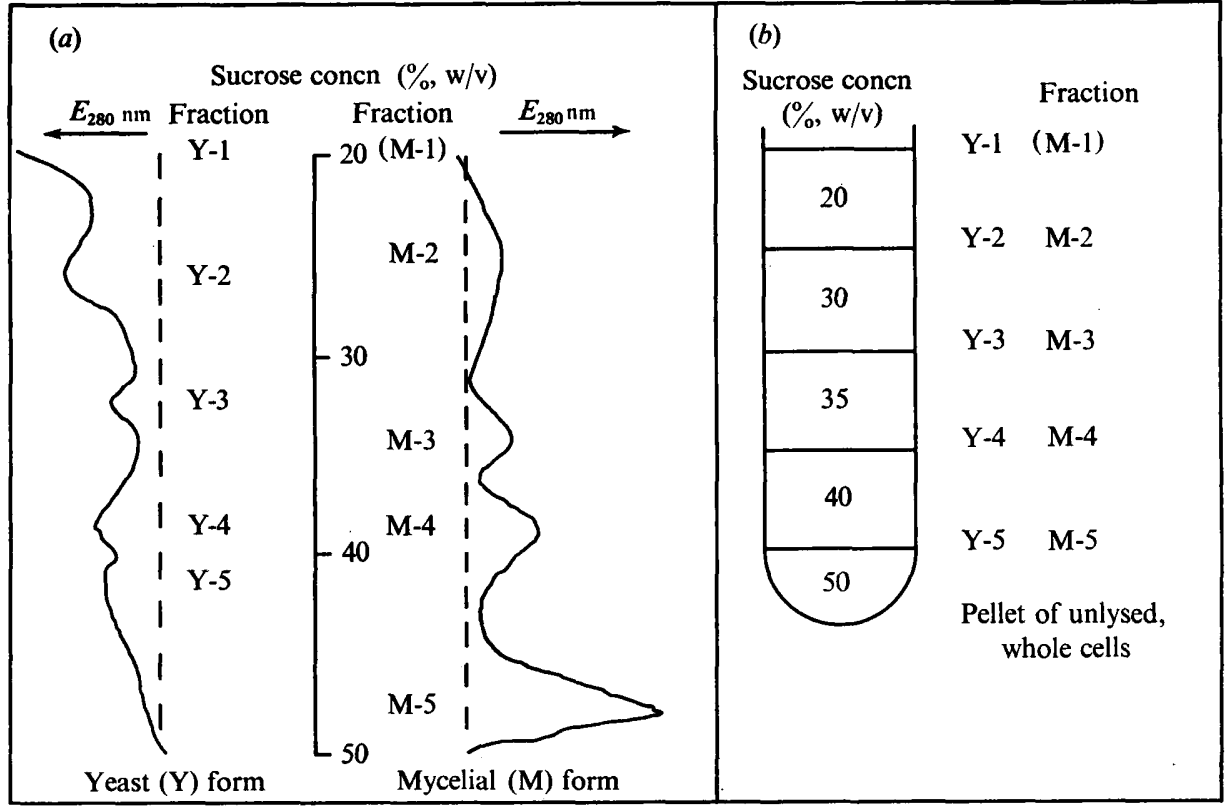

Fig. I. (a) Distribution of protein from $5000 \mathrm{~g}$ pellet prepared from lysed protoplasts of the yeast and mycelial forms of $C$. albicans after fractionation on continuous sucrose gradient. (b) Discontinuous sucrose gradient designed to fractionate the $5000 \mathrm{~g}$ pellet from lysed protoplasts of the yeast and mycelial forms.

cell dry wt $/ \mathrm{ml}$ in Io $\mathrm{ml}$ of $0.0 \mathrm{I} \mathrm{M}$-carbonate/bicarbonate buffer $\mathrm{pH} 9 \cdot 2$, containing $0.6 \mathrm{M}$ potassium chloride. Dansyl chloride in acetone (O.I mM; $\mathrm{G}^{3} \mathrm{H}$ dansyl chloride, $0 \cdot \mathrm{I}$ $\mathrm{mCi} / \mathrm{ml}$; The Radiochemical Centre, Amersham, Buckinghamshire) was added in $0.0 \mathrm{I} \mathrm{ml}$ amounts at $3 \mathrm{~min}$ intervals for $30 \mathrm{~min}$. Protoplasts were then harvested, washed in the same buffer, lysed and fractionated as described above.

(ii) Iodination. Protoplasts were suspended at a cell density of $20 \mathrm{mg}$ whole-cell dry wt $/ \mathrm{ml}$ in $10 \mathrm{ml}$ of $0.05 \mathrm{M}$-citrate/phosphate buffer $\mathrm{pH} 7.4$, containing $0.6 \mathrm{M}$-potassium chloride. Lactoperoxidase (Sigma) and carrier-free $\mathrm{Na}^{125}$ (The Radiochemical Centre) were added to final concentrations of $0.03 \mathrm{mg} / \mathrm{ml}$ and $0.02 \mathrm{mCi} / \mathrm{ml}$, respectively. The reaction was started by the addition of $0.01 \mathrm{ml}$ of $0.05 \mathrm{M}$-hydrogen peroxide and continued by further $0.0 \mathrm{I} \mathrm{ml}$ additions at $2 \mathrm{~min}$ intervals for $10 \mathrm{~min}$. Protoplasts were then harvested, washed, lysed and fractionated as described above.

The radioactivity of the samples was determined by using a Packard 3375 scintillation spectrometer, with Triton X-IOO-toluene ( $\mathrm{I}: 2, \mathrm{v} / \mathrm{v})$ containing $5 \mathrm{~g}$ 2,5-diphenyloxazole (PPO)/I as scintillant.

Electron microscopy. Plasma membrane preparations were negatively stained with $2 \%$ $(\mathrm{w} / \mathrm{v})$ potassium phosphotungstate and observed by means of an AEI EM6B electron microscope.

Succinic dehydrogenase. Succinic dehydrogenase (EC. I.3.99.I) was assayed spectrophotometrically by measuring $\Delta E_{600}$ as 2,6-dichlorophenol indophenol (DCPIP) is converted to leucophenol. The method used was adapted from that of Green, Mii \& Kohout (I955) and each incubation contained (per $3 \mathrm{ml}$ ): 50 to I $50 \mu \mathrm{g}$ protein, $60 \mu \mathrm{g} \mathrm{DCPIP}, 3 \mu \mathrm{mol} \mathrm{KCN}$,

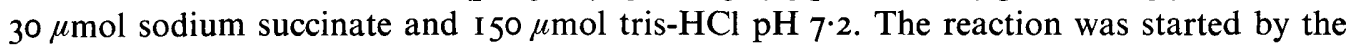


addition of succinate and the molar extinction coefficient was taken to be $\mathrm{I} \cdot 6 \mathrm{I} \times \mathrm{IO}^{3} \mathrm{l} / \mathrm{mol} / \mathrm{cm}$ (Crane et al. 1956).

Bulk preparation. To scale up the preparation procedure, the following modifications were made. For the initial fractionation of the $5000 \mathrm{~g}$ pellet, it was resuspended in $5 \mathrm{ml}$ of $50 \%$ (w/v) sucrose made up as described previously and $40 \%$ sucrose layered on top. After centrifugation ( $2 \mathrm{~h}, 82500 \mathrm{~g}$, in a SW 27 rotor) the material sedimenting at the interface was collected and pelleted before being resuspended in $40 \%$ sucrose. This was then centrifuged a second time ( $\mathrm{I} \cdot 5 \mathrm{~h}$ at $82500 \mathrm{~g}$ in a SW 27 rotor) and the pellet (plasma membrane) washed six times with $\mathrm{O} \cdot \mathrm{I} \mathrm{M}$-tris- $\mathrm{HCl}$ buffer $\mathrm{pH} 7.2$ containing $0.0 \mathrm{I} \mathrm{M}-\mathrm{Mg}^{2+}$ ions, before being lyophilized and stored at $-20^{\circ} \mathrm{C}$.

Protein estimation. The total protein content of the plasma membrane was determined by using the Folin-Ciocalteau reagent of Lowry, Rosebrough, Farr \& Randall (I95I). The membranes were dispersed in $0.01 \%(\mathrm{w} / \mathrm{v})$ sodium dodecyl sulphate (SDS); this has no effect on the intensity of colour developed.

Carbohydrate estimation and characterization. Total carbohydrate was determined using the anthrone reagent described by Trevelyan \& Harrison (1952); again the membranes were dispersed in $0.01 \%$ SDS before analysis. Hexosamines were assayed by means of a slight modification of the method of Ghuysen, Tipper \& Strominger (1966). Sixteen g dimethyl amino benzaldehyde (Rondle \& Morgan, 1955) was dissolved in glacial acetic acid to a volume of $95 \mathrm{ml}$, and $5 \mathrm{ml}$ conc. $\mathrm{HCl}$ added. This was diluted $2: 5(\mathrm{v} / \mathrm{v})$ with glacial acetic acid to give the colour reagent. Membrane samples and glucosamine standards were hydrolysed in vacuo with $20 \mu \mathrm{l}$ of $3 \mathrm{M}-\mathrm{HCl}$. After $4 \mathrm{~h}$ at $95^{\circ} \mathrm{C}$ these were neutralized with $20 \mu \mathrm{l}$ of $3 \mathrm{M}-\mathrm{NaOH}$. Samples $(30 \mu \mathrm{l})$ were removed and io $\mu \mathrm{l}$ saturated $\mathrm{NaHCO}_{3}$ added, followed by $2 \mu \mathrm{l}$ acetic anhydride. The samples were allowed to stand for $10 \mathrm{~min}$ at $20{ }^{\circ} \mathrm{C}$ before being heated at $100{ }^{\circ} \mathrm{C}$ for $3 \mathrm{~min}$ and then cooled in ice. Fifty $\mu \mathrm{l}$ of a $5 \%(\mathrm{w} / \mathrm{v})$ solution of $\mathrm{K}_{2} \mathrm{~B}_{4} \mathrm{O}_{7}$ was added and the tubes heated at $100{ }^{\circ} \mathrm{C}$ for a further $7 \mathrm{~min}$. After cooling in ice, $700 \mu \mathrm{l}$ of colour reagent were added and the samples incubated for $20 \mathrm{~min}$ at $37^{\circ} \mathrm{C}$ before measuring the extinction at $585 \mathrm{~nm}$.

The carbohydrate content of the plasma membrane was further analysed by gas-liquid chromatography (see below). However, before this it was necessary to separate neutral sugars from amino sugars. Samples of membrane were hydrolysed with $\mathrm{I} M-\mathrm{H}_{2} \mathrm{SO}_{4}$ for $\mathrm{I} \mathrm{h}$ at $100{ }^{\circ} \mathrm{C}$ in sealed tubes, then neutralized with Amberlite IR $45(\mathrm{OH})$. The supernatant fluid was removed, the resin washed once with an equal volume of $\mathrm{H}_{2} \mathrm{O}$ and the extracts combined. Amberlite IRC $50(\mathrm{H})$ was used to separate neutral and amino sugars, but before use the resin was pretreated as follows. A column of resin $(80 \times 10 \mathrm{~mm})$ was prepared and washed with 2 vols. I M-NaOH, followed by 6 vols. $\mathrm{H}_{2} \mathrm{O}$. This was then equilibrated with citrate/ phosphate buffer $\mathrm{pH} 7 \cdot 0$ for $\mathrm{I} O \mathrm{~min}$ and washed with 4 vols. $\mathrm{H}_{2} \mathrm{O}$ (Exley, I957). A few grams of resin were added to the hydrolysates, which were allowed to stand for $\mathrm{I} \mathrm{h}$ at $20^{\circ} \mathrm{C}$ with occasional shaking. The supernatant fluid was removed, the resin washed once with an equal volume of water and the two extracts, containing the neutral sugars, combined. Amino sugars were eluted twice with $0.5 \mathrm{ml} \mathrm{I} \mathrm{M}-\mathrm{HCl}$, the extracts being combined and dried twice over $\mathrm{NaOH}$ to remove $\mathrm{HCl}$. The neutral sugars were further purified by washing through an Amberlite IR I $20(\mathrm{H})$ column $(50 \times 10 \mathrm{~mm})$ with three to four volumes of water. The column eluate was neutralized with Amberlite IR $45(\mathrm{OH})$ and dried under reduced pressure.

Nucleic acid extraction and estimation. Total nucleic acid was extracted three times with $0.5 \mathrm{M}$-perchloric acid for $30 \mathrm{~min}$ at $70^{\circ} \mathrm{C}$ and assayed by measuring $\mathrm{E}_{260}$.

Lipid extractions. Lipids were extracted with chloroform-methanol $(2: \mathrm{I}, \mathrm{v} / \mathrm{v})$; three 
extractions were made, at least one being overnight. All extractions were carried out under nitrogen and the lipid extracts were stored under nitrogen at $-20^{\circ} \mathrm{C}$. The total lipid extracts were washed according to the method of Folch, Lees \& Sloane-Stanley (I957) and assayed gravimetrically.

Separation and analysis of lipids. Neutral lipids and phospholipids were separated by onedimensional thin-layer chromatography, initial identification being made on microscope slide t.l.c. plates spread with a $0.25 \mathrm{~mm}$ thick layer of Anasil G (Analabs Inc., North Haven, Connecticut, U.S.A.). The solvent system used for separating neutral lipids was similar to that described by Wood et al. (I964), namely light petroleum (b.p. 40 to $60{ }^{\circ} \mathrm{C}$ ): diethyl ether:acetic acid (80:20:2, by vol.). Neutral lipid spots were located with iodine vapour or by chromic acid charring. The individual components were identified by comparing their mobilities with those of known standards. Free sterols could also be detected by using the Liebermann-Buchard reagent as described by Starr \& Parks (1972). For further studies individual spots were scraped off and"eluted with chloroform $(3 \times 3 \mathrm{ml})$. Triglycerides were assayed by using the chromotropic acid reagent described by Van Handel \& Zilversmit (1957) with triolein as standard, whilst free fatty acids were assayed according to the method of Heinen \& de Vries (1966) with oleic acid as standard. Sterols and sterol esters were assayed by measuring their extinction at $28 \mathrm{I} \cdot 5 \mathrm{~nm}$ (Breivik \& Owades, 1957). This method measures only ergosterol and 24,28-dehydroergosterol. Since gas-liquid chromatography revealed the presence of other precursors of ergosterol, in some cases in large proportions, values for sterol and sterol ester content have been corrected accordingly.

Phospholipids were separated by using the solvent system of Skipski, Peterson \& Barclay (1964), i.e. chloroform-methanol-acetic acid-water (25:15:4:2, by vol.). Phospholipid spots were detected by using iodine vapour, chromic acid charring or the molybdenum blue reagent of Dittmer \& Lester (1964). Individual components were identified by specific sprays and by comparing their $R_{F}$ values with those of standards. Ninhydrin-positive phospholipids were identified by spraying with a $0.2 \%(\mathrm{w} / \mathrm{v})$ solution of ninhydrin in butanol, followed by warming in an oven at $100{ }^{\circ} \mathrm{C}$. Choline-containing lipids were detected by using the Dragendorff reagent of Skidmore \& Entenman (1962). For further analysis individual spots were scraped off and eluted with chloroform $(3 \times 3 \mathrm{ml})$. Phosphorus was assayed by the ashing procedure of Chen, Toribara \& Warner (1956).

Gas-liquid chromatography. (i) Fatty acids. Methyl esters of fatty acids were prepared according to the method of Nichols \& Moorhouse (1969). They were separated by gas-liquid chromatography using a Pye series I04 chromatograph, fitted with a polyethylene glycol adipate (10\%, w/w, on celite) column. The column temperature was $190{ }^{\circ} \mathrm{C}$ and the carrier gas argon. Methyl esters of fatty acids were identified by comparing their retention times with those of known fatty acid methyl esters in mixtures. The area under each componentfatty-acid peak was calculated by multiplying peak height by the width at half the height and expressed as a percentage of the total area.

(ii) Sterols and sterol esters. Sterols from sterol esters were prepared by extraction after saponification by means of the method of Breivik \& Owades (1957). These and free sterols were then separated, without further modification, by gas-liquid chromatography using a polydimethylsiloxane (JXR) column prepared as described by Vandenheuval \& Court (1968). Individual sterols were identified by comparing their retention times with those of standards. When standards were not available, tentative identifications could be made on the basis of the data given by Vandenheuval \& Court (1968). The areas under peaks were calculated as described above and expressed as percentages of the total areas.

(iii) Sugars. Neutral and amino sugars were silylated before chromatographic analysis 
(Sweeley, Bentley, Makita \& Wells, 1963). Neutral sugar samples were dissolved in $0.5 \mathrm{ml}$ anhydrous pyridine (dried over a molecular sieve, BDH type $4 \mathrm{~A}$ ) and heated for $30 \mathrm{~min}$ at $100{ }^{\circ} \mathrm{C}$ to equilibrate isomers. After cooling, $0.1 \mathrm{ml}$ hexamethyl disilazane and $0.05 \mathrm{ml}$ trimethyl chlorsilane were added and the samples incubated for $\mathrm{I}$ to $2 \mathrm{~h}$ at $20^{\circ} \mathrm{C}$. One $\mathrm{ml}$ petroleum ether (b.p. 60 to $80^{\circ} \mathrm{C}$ ) was added and the pyridine removed by washing three times with water. The trimethylsilyl derivatives were separated on a polyethylene glycol adipate column (see above). The column temperature was initially $90^{\circ} \mathrm{C}$ and rose at a rate of $4{ }^{\circ} \mathrm{C} / \mathrm{min}$ to $190^{\circ} \mathrm{C}$, being held at this temperature until no more peaks were observed.

Amino sugars were silylated as described above except that the reaction was allowed to proceed overnight at $20^{\circ} \mathrm{C}$. This fraction was analysed in the same way as the neutral sugar fraction. Silylated inositol was included as a marker, and identification of individual components was based on relative retention times compared with those of standard sugar derivatives. The results were expressed as above.

Amino acid analysis. Samples of yeast- and mycelial-form plasma membranes were hydrolysed in vacuo with $6 \mathrm{M}-\mathrm{HCl}$, containing $0.1 \%(\mathrm{v} / \mathrm{v})$ mercaptoethanol, for $\mathrm{I} \mathrm{h}$ at $105{ }^{\circ} \mathrm{C}$ (Brown \& Perham, 1973). The samples were then dried several times over $\mathrm{NaOH}$ and stored at $-20^{\circ} \mathrm{C}$ before analysis. Amino acids were separated on a Beckman model $\mathrm{r} 20 \mathrm{C}$ amino acid analyser fitted with long $(550 \mathrm{~mm})$ and short $(90 \mathrm{~mm})$ columns, the resin used being Beckman type UR 30. The samples were dissolved in citrate buffer $\mathrm{pH} 2 \cdot 2$ and applied in $0.7 \mathrm{ml}$ portions. The column temperature was $56.5{ }^{\circ} \mathrm{C}$ and the reaction coil temperature $79^{\circ} \mathrm{C}$. Each run lasted approximately $200 \mathrm{~min}$. The area under the various peaks was calculated and the results converted to $\mathrm{mol} / \mathrm{I} 00 \mathrm{~mol}$ total amino acid.

\section{RESULTS \\ Growth}

Candida albicans 6406 grew in the yeast form in the GSV medium with a mean generation time of $72 \mathrm{~min}$ and reached a final suspension density of $2.5 \mathrm{mg} / \mathrm{ml}$ (Fig. 2a). Germ-tubes were produced in SSV medium after $5 \mathrm{~h}$ static incubation at $37^{\circ} \mathrm{C}$, it being necessary to use as inoculum cells washed from a nutrient agar slope. The mycelial (pseudohyphal) form was maintained for a further 5 to $7 \mathrm{~h}$, during which time more than $90 \%$ of the cells possessed germ-tubes (Fig. $2 b$ ). The suspension density increased exponentially during this initial Io to $12 \mathrm{~h}$ period but there was practically no increase upon subsequent incubation and the organism became progressively more yeast-like. The cessation of growth could have been due to a number of factors, including the inability of $C$. albicans to utilize starch and the observed decrease in the $\mathrm{pH}$ value of the medium $(\mathrm{pH} 6 \cdot 0$ to $3 \cdot 0)$.

\section{Protoplast formation}

Osmotically sensitive protoplasts were released from the yeast form of $C$. albicans after 6 to $9 \mathrm{~h}$ incubation with snail gut juice. The percentage yield was low $(50 \%)$ and in view of the prolonged incubation period, together with the presence in the enzyme preparation of proteases and lipases (Anderson \& Millbank, 1966), it was felt unwise to use this method of producing protoplasts for the production of plasma membranes. Protoplasts were not released after $12 \mathrm{~h}$ incubation with the Cytophaga enzymes. After 45 to $75 \mathrm{~min}$ incubation with the enzyme preparation 'strepzymes', protoplasts were released from both the yeast and mycelial forms. Yields of protoplasts were better than $90 \%$ as judged by osmotic fragility. In all subsequent experiments this method was used for the production of protoplasts from cells of C. albicans. 

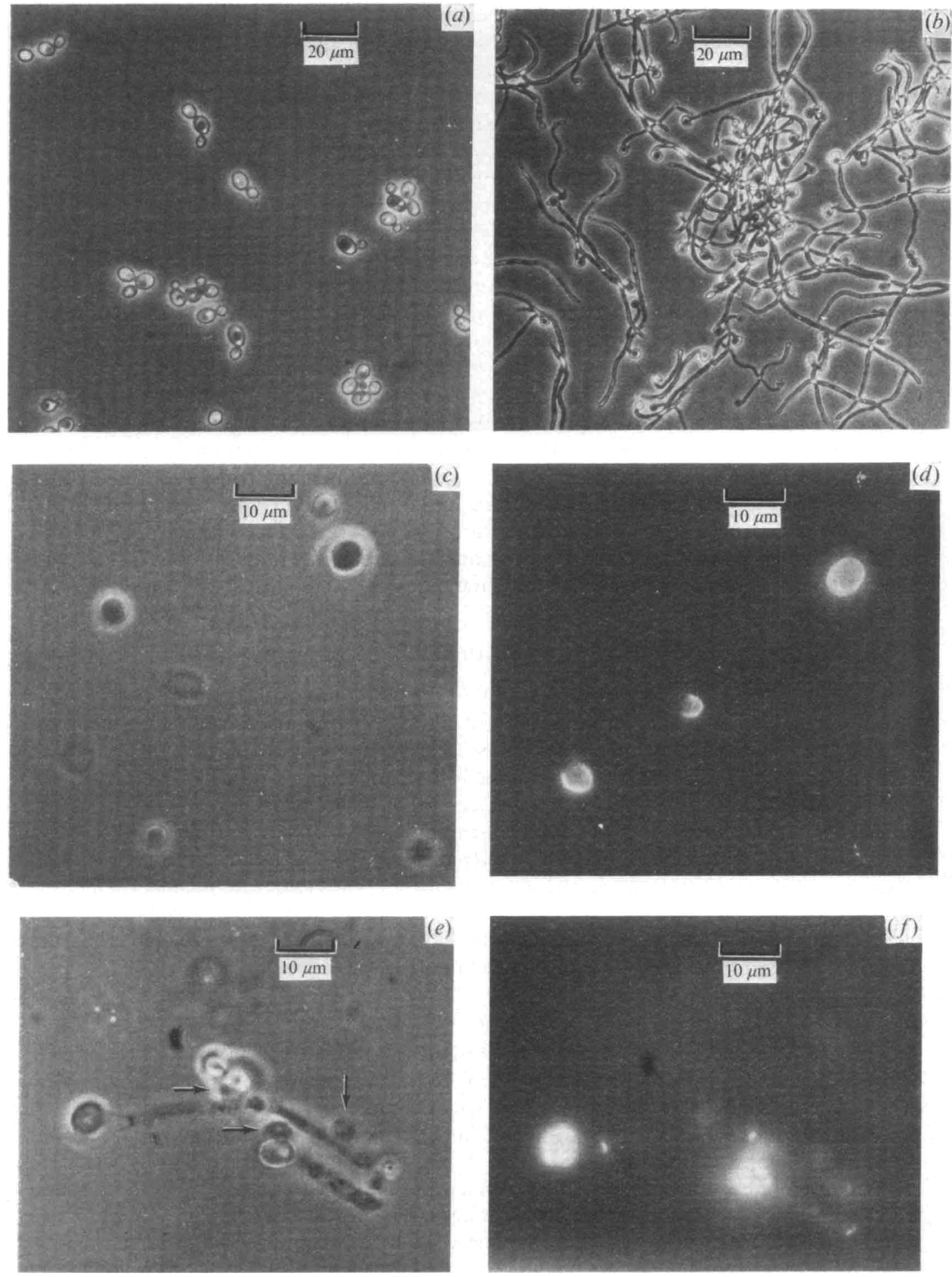

Fig. 2. (a) Phase-contrast micrograph of the yeast form of $C$. albicans. (b) Phase-contrast micrograph of the mycelial form of $C$. albicans. (c) Protoplasts, wall fragments and one yeast cell after labelling with Tinopal BOPT; see text. $(d)$ Same field viewed under u.v. illumination; only whole cell and wall fragments show fluorescence due to labelling with optical brightener. (e) Protoplasts (arrowed) emerging from hyphae of mycelial form after labelling with Tinopal BOPT. $(f)$ Same field viewed under u.v. illumination; both wall and protoplasts have been labelled. 
Table 2. Percentage distribution of radioactivity $\left({ }^{3} \mathrm{H}\right.$ and $\left.{ }^{125} \mathrm{I}\right)$ in fractions I to $5^{*}$ upon fractionation of the $5000 \mathrm{~g}$ pellet prepared from radioactively labelled protoplasts from the yeast and mycelial forms of Candida albicans

\begin{tabular}{|c|c|c|c|c|c|c|}
\hline \multirow{3}{*}{$\begin{array}{c}\text { Fraction } \\
\text { no. }\end{array}$} & & & \multicolumn{4}{|c|}{${ }^{125}$ Iodine $\ddagger$} \\
\hline & \multicolumn{2}{|c|}{$\mathrm{G}^{3} \mathrm{H}$ dansyl chloride $\dagger(\%)$} & \multicolumn{3}{|c|}{$\begin{array}{c}10^{-3} \times \text { Specific } \\
\text { activity }\end{array}$} & \multirow{2}{*}{$\begin{array}{l}\text { I0 } \\
\text { activity } \\
\text { (c.p.m. } / \mathrm{mg} \\
\text { protein) }\end{array}$} \\
\hline & Yeast form & Mycelial form & $(\%)$ & protein) & $(\%)$ & \\
\hline $\mathbf{I}$ & $12 \pm 2$ & - & $8 \pm I$ & $3 \cdot 7$ & - & - \\
\hline 2 & $14 \pm 1$ & $15 \pm 2$ & $14 \pm 4$ & $4 \cdot 8$ & $6 \pm 3$ & 0.7 \\
\hline 3 & $10 \pm 3$ & I8 $( \pm 0)$ & $10 \pm 3$ & $2 \cdot 7$ & $7 \pm 3$ & $2 \cdot 7$ \\
\hline 4 & $22 \pm I$ & $2 I \pm I$ & $10 \pm 3$ & $2 \cdot I$ & $19 \pm 6$ & $4 \cdot 3$ \\
\hline & $42 \pm I$ & $46 \pm 2$ & $58 \pm 3$ & $5 \cdot I$ & $69 \pm 9$ & $6 \cdot 1$ \\
\hline & \multicolumn{6}{|c|}{$\begin{array}{l}\text { * See Fig. } 1 b \text {. } \\
\text { Two experiments with each form of the organism. Standard deviations are given. } \\
\text { Three experiments with each form of the organism. } \\
\S \text { Standard deviations are given. }\end{array}$} \\
\hline
\end{tabular}

\section{Characterization of protoplasts}

The viability of protoplasts was estimated by their ability to regenerate cell walls and produce visible colonies on suitable media. It was found that 80 to $85 \%$ of the protoplasts produced by 'strepzyme' digestion of the yeast form were viable.

Whole organisms showed marked fluorescence under u.v. illumination when labelled with either Tinopal BOPT or fl-Con A. Protoplasts from the yeast form were not labelled with Tinopal BOPT (Fig. $2 c, d$ ) and in other systems it has been concluded from this that no wall material remains attached to the protoplasts (Gull, Moore \& Trinci, I972). However, protoplasts derived from the mycelial form were labelled, indicating a difference between the two forms (Fig. $2 e, f$ ). Fluorescein-conjugated Concanavalin A did label protoplasts from both forms of $C$. albicans, indicating that there are carbohydrate residues, possibly in the form of glycosylated membrane proteins, on the protoplast surface.

\section{Plasma membrane fractionation}

The $5000 \mathrm{~g}$ pellet obtained from lysed protoplasts was fractionated into four or five membrane-containing bands by density-gradient centrifugation (Fig. I $a$ ). Band I, absent from the mycelial preparations, consisted mainly of lipid droplets attached to membrane fragments. The results of the experiments in which the protoplast membrane was either dansylated or iodinated before lysis and fractionation are shown in Table 2. The plasma membrane of $C$. albicans is unlikely to be permeable to the enzyme lactoperoxidase (mol. wt approx. 73000) and iodination of surface proteins by the enzyme promises to be a specific and sensitive labelling technique. Indeed this method gave consistently better results than dansyl chloride labelling. The material from band 5 contained the highest total radioactivity and the highest specific radioactivity (Table 2). Centrifugation of the membranous material from band 5 on similar discontinuous sucrose gradients resulted in a redistribution of part of the protein from this band but not the radioactivity, whilst a third centrifugation resulted in only a slight (less than $4 \%$ ) distribution of protein. From this it was concluded that separation of the membranous components sedimenting at $5000 \mathrm{~g}$ on the discontinuous sucrose density gradients, followed by one further centrifugation of the material from band 5 , resulted in a preparation of plasma membrane in which the contamination with other membranous components of the cell was less than $4 \%$. 


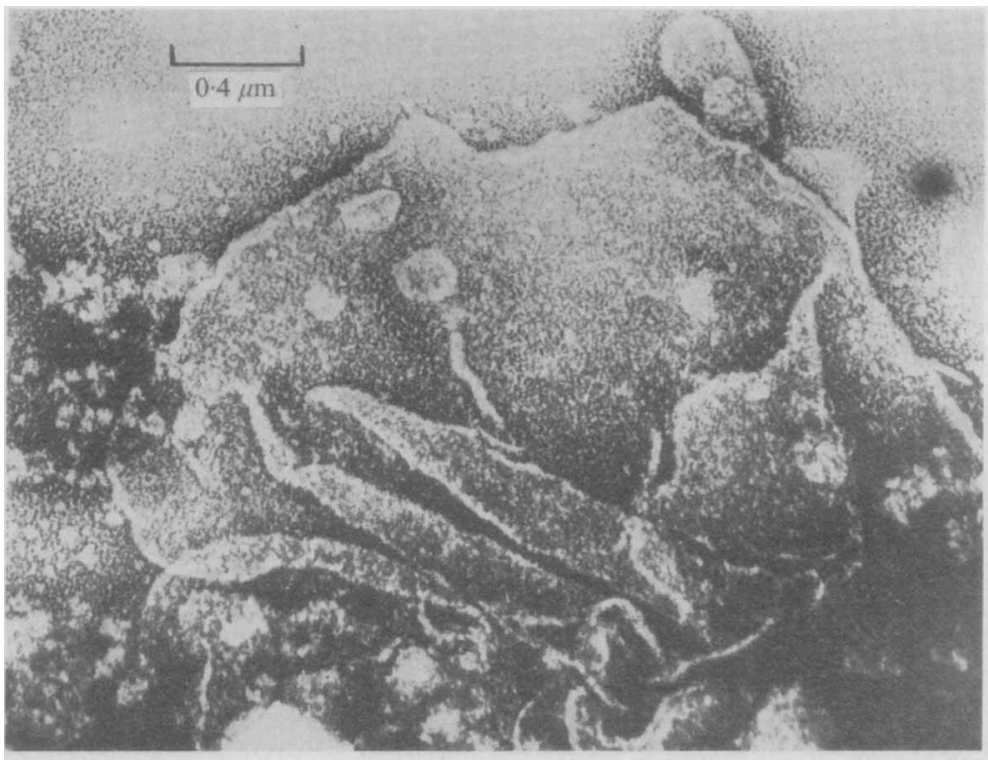

Fig. 3. Electron micrograph of purified plasma membrane from the yeast form, negatively stained with $2 \%$ potassium phosphotungstate.

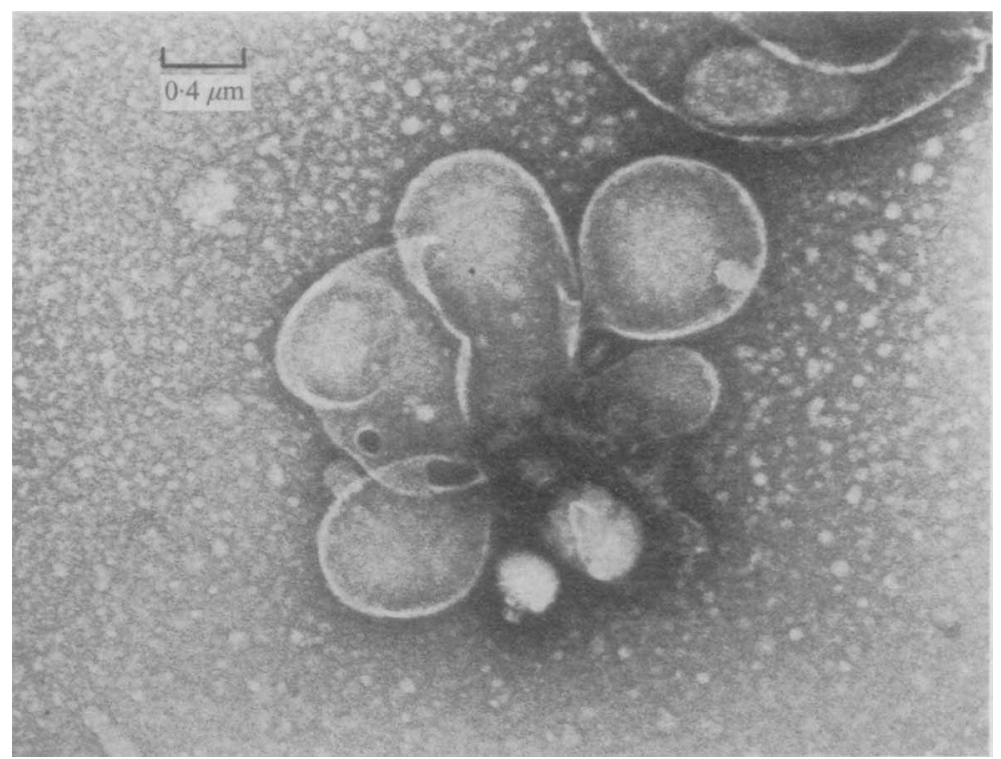

Fig. 4. Electron micrograph of purified plasma membrane from the mycelial form, negatively stained as in Fig. 3.

The presence of ${ }^{3} \mathrm{H}$ and ${ }^{125} \mathrm{I}$ in bands other than band 5 was probably the result of entrapment in vesicles of unreacted dansyl chloride or ${ }^{125}$ I. Further centrifugation of the material from these bands resulted in a loss of radioactivity, supporting this interpretation. Vesicular entrapment was probably also the cause of the high degree of contamination found in band 5 after one centrifugation. Further centrifugation studies have shown that all bands were 
Table 3. Distribution of succinic dehydrogenase activity upon fractionation of protoplasts from the yeast and mycelial forms

\begin{tabular}{|c|c|c|c|c|}
\hline \multirow{2}{*}{ Fraction } & \multicolumn{2}{|c|}{ Yeast form } & \multicolumn{2}{|c|}{ Mycelial form } \\
\hline & $\begin{array}{l}\text { Total activity } \\
(\mu \mathrm{mol} \\
\text { DCPIP } / \mathrm{min})\end{array}$ & $\%$ Total & $\begin{array}{l}\text { Total activity } \\
(\mu \mathrm{mol} \\
\text { DCPIP/min })\end{array}$ & $\%$ Total \\
\hline Whole protoplasts & $37 \cdot 3$ & 100 & $15 \cdot 7$ & 100 \\
\hline $5000 \mathrm{~g}$ Supernatant & 28.0 & 75 & 17.5 & III \\
\hline $5000 \mathrm{~g}$ Pellet & $17 \cdot 0$ & 45 & $2 \cdot I$ & 13 \\
\hline Unlysed cells & II $\cdot 8$ & 32 & $\mathrm{I} \cdot 4$ & 9 \\
\hline Crude membranes & 0.8 & 2 & 0.6 & 4 \\
\hline
\end{tabular}

Table 4. Gross chemical composition of plasma membranes derived from the yeast and mycelial forms of C. albicans

The values in this and all subsequent Tables are the means of results from three independent preparations of both types of plasma membrane; standard deviations are given.

$\begin{array}{lcc}\text { Component } & \text { Yeast form }(\%) & \text { Mycelial form }(\%) \\ \text { Protein } & 52 \cdot 0 \pm 2 \cdot 0 & 45 \cdot 0 \pm 3 \cdot 0 \\ \text { Lipid } & 43 \cdot 0 \pm 3 \cdot 0 & 31 \cdot 0 \pm 3 \cdot 0 \\ \text { Carbohydrate } & 9 \cdot 0 \pm 0 \cdot 5 & 25 \cdot 0 \pm 4 \cdot 0 \\ \text { Nucleic acid } & 0 \cdot 3 \pm 0 \cdot 1 & 0.5 \pm 0 \cdot 1\end{array}$

subject to such contamination (Marriott, unpublished data). This provides a second explanation for the appearance of radioactivity in bands I to 4, namely entrapment of plasma membrane fragments in other membranous vesicles.

\section{Electron microcospy}

Negatively stained preparations of plasma membranes from the yeast and mycelial forms are shown in Figs. 3 and 4.

\section{Succinic dehydrogenase}

Table 3 shows the distribution of succinic dehydrogenase upon fractionation of protcplasts. The majority of the activity associated with the $5000 \mathrm{~g}$ pellet could be accounted for by the presence of unlysed whole cells. These could be separated from the crude membrane fraction by layering the $5000 \mathrm{~g}$ pellet on top of $50 \%(\mathrm{w} / \mathrm{v})$ sucrose and centrifuging at $82500 \mathrm{~g}$ for $\mathrm{I} h$. Unlysed whole cells were sedimented and crude membranes remained on the top.

\section{Bulk preparation}

By means of the modified procedure described previously, yields of 40 to $50 \mathrm{mg}$ dry wt of plasma membrane could be obtained from I $g$ dry wt of either the yeast or mycelial form, i.e. 4 to $5 \%$ yield.

\section{Gross chemical composition}

The gross chemical compositions of plasma membranes obtained from the yeast and mycelial forms of Candida albicans are given in Table 4. The major components were found to be lipid and protein, although a substantial amount of carbohydrate was found associated with plasma membrane from the mycelial form of the organism. It is not known whether this is an integral part of the membrane or not. The mode of release of protoplasts from the mycelial form (Fig. $2 e$ ) would suggest that it is unlikely that this material represents undigested wall components. 
Table 5. Neutral lipid and phospholipid composition of yeast- and mycelial-form plasma membranes

$\begin{array}{lcc}\begin{array}{c}\text { Component } \\ \text { Neutral lipids }\end{array} & \begin{array}{c}\text { Yeast form* } \\ (\%)\end{array} & \begin{array}{c}\text { Mycelial form* } \\ (\%)\end{array} \\ \text { Sterol esters } & & \\ \text { Triglycerides } & 40 \pm 4 & 28 \pm 1 \\ \text { Free fatty acids } & 24 \pm 3 & 36 \pm 2 \\ \text { Free sterols } & 17 \pm 3 & 27 \pm 2 \\ \text { Phospholipids } & 19 \pm 2 & 9 \pm 1 \\ \text { Phosphatidyl ethanolamine } & & \\ \text { Phosphatidyl serine } & 70 \pm 4 & 50 \pm 4 \\ \text { Phosphatidyl choline } & 11 \pm 2 & - \\ \text { Sphingolipid } & 4 \pm 1 & 50 \pm 4 \\ \end{array}$

* Values are expressed as percentages of the total material in each fraction.

Table 6. Free sterol composition of yeast- and mycelial-form plasma membranes

\begin{tabular}{|c|c|c|c|}
\hline Component & $\begin{array}{l}\text { Relative } \\
\text { retention time* }\end{array}$ & $\begin{array}{c}\text { Yeast form } \dagger \\
(\%)\end{array}$ & $\begin{array}{l}\text { Mycelial form } \dagger \\
(\%)\end{array}$ \\
\hline Squalene & 0.446 & $2 \cdot 0( \pm 0.0)$ & $2 \cdot 0 \pm 0 \cdot I$ \\
\hline Breakdown products of ergosterol & $\left\{\begin{array}{l}0.588 \\
0.635\end{array}\right.$ & $\begin{array}{l}7 \cdot 0 \pm 1 \cdot 0 \\
5 \cdot 0 \pm 1 \cdot 0\end{array}$ & $\begin{array}{r}11 \cdot 0 \pm 3.0 \\
6 \cdot 0 \pm 2 \cdot 0\end{array}$ \\
\hline Calciferol & 0.918 & $12 \cdot 0 \pm 4 \cdot 0$ & Trace \\
\hline Zymosterol & $0.940(0.944)$ & ND & $16 \cdot 0 \pm 2 \cdot 0$ \\
\hline Ergosterol & $\mathrm{I} \cdot 000$ & $50 \cdot 0 \pm 5 \cdot 0$ & $42 \cdot 0 \pm 6 \cdot 0$ \\
\hline$(24,28$-Dehydroergosterol $) \ddagger$ & $\mathbf{I} \cdot 087$ & $7 \cdot 0( \pm 0.0)$ & $1 I \cdot 0 \pm 3 \cdot 0$ \\
\hline (3- $\beta$-Hydroxy-24-methyl cholesta-5,7-diene) & $I \cdot I 70(I \cdot I 64)$ & $7 \cdot 0 \pm 2 \cdot 0$ & $9 \cdot 0 \pm 2 \cdot 0$ \\
\hline$\left(4,4^{\prime}\right.$-Dimethyl zymosterol) & $I \cdot 360(I \cdot 364)$ & $6 \cdot 0 \pm 2 \cdot 0$ & ND \\
\hline
\end{tabular}

ND, Not detected.

$*$ Retention time relative to ergosterol $=\mathrm{I} \cdot 000$. Relative retention times for different 'runs' varied by less than \pm 0.005 . Figures in parentheses refer to calculated relative retention times and components in parentheses have been tentatively identified on the basis of these figures.

$\uparrow$ See text.

$\ddagger$ Identified by u.v. spectrum.

\section{Lipid composition}

Table 5 shows the neutral and phospholipid composition of yeast- and mycelial-form plasma membranes. Phospholipids accounted for 7 and $10 \%$ of the dry weight of the membranes from the yeast and mycelial forms, respectively. Both free and esterified sterol contents have been corrected in the light of g.l.c. data. Sterol esters were assumed, for the purpose of analysis, to be all sterol oleates. These corrections were necessary because $E_{281 \cdot 5}$ measurements estimate only the amount of ergosterol and 24,28-dehydroergosterol present and, as can be seen from Tables 6 and 7, these are not the only sterols found in either fraction. Esterification of ergosterol with $\mathrm{C}_{16}$ or $\mathrm{C}_{18}$ fatty acids does not affect the absorption coefficient if one takes into account the increase in molecular weight (T. Y. Koh, University of Cambridge, personal communication). Complete u.v. spectra of free sterol and sterol ester extracts indicated the presence of 24,28-dehydroergosterol which has an extra absorption peak at $230 \mathrm{~nm}$ (Breivik \& Owades, 1957). 
Table 7. Sterol composition of the sterol ester fraction from yeast- and mycelial-form plasma membranes

\begin{tabular}{|c|c|c|c|}
\hline Component & $\begin{array}{c}\text { Relative } \\
\text { retention time* }\end{array}$ & $\begin{array}{l}\text { Yeast form } \dagger \\
(\%)\end{array}$ & $\begin{array}{c}\text { Mycelial form } \dagger \\
(\%)\end{array}$ \\
\hline Unidentified & 0.557 & $8 \cdot 0 \pm 3 \cdot 0$ & $4 \cdot 0( \pm 0 \cdot 0)$ \\
\hline Unidentified & 0.725 & $6 \cdot 0 \pm 2 \cdot 0$ & $2 \cdot 0( \pm 0.0)$ \\
\hline Unidentified & 0.830 & $12 \cdot 0 \pm 3 \cdot 0$ & $5 \cdot 0 \pm 2 \cdot 00$ \\
\hline Zymosterol & $0.940(0.944)$ & $32 \cdot 0 \pm 5 \cdot 0$ & $36 \cdot 0 \pm 3 \cdot 0$ \\
\hline Ergosterol & $1 \cdot 000$ & $10 \cdot 0 \pm 2 \cdot 0$ & $10 \cdot 0 \pm 1 \cdot 0$ \\
\hline$(24,28-D e h y d r o e r g o s t e r o l) \ddagger$ & $1 \cdot 087$ & $10 \cdot 0 \pm 2 \cdot 0$ & $12 \cdot 0 \pm 1 \cdot 0$ \\
\hline (3- $\beta$-Hydroxy-24-methyl cholesta-5,7-diene) & $I \cdot 170(I \cdot I 64)$ & $7 \cdot 0 \pm 2 \cdot 0$ & $6 \cdot 0( \pm 0.0)$ \\
\hline (3- $\beta$-Hydroxy-24-methyl cholesta-7-ene) & $1 \cdot 205(1 \cdot 210)$ & ND & $6 \cdot 0( \pm 0 \cdot 0)$ \\
\hline (Fecosterol) & $1 \cdot 220(1 \cdot 217)$ & $4 \cdot 0 \pm 1 \cdot 0$ & ND \\
\hline (Episterol) & $I \cdot 325(I \cdot 318)$ & $8 \cdot 0 \pm 3 \cdot 0$ & $19 \cdot 0 \pm 2 \cdot 0$ \\
\hline
\end{tabular}

ND, Not detected.

* See Table 4.

+ See text.

$\ddagger$ Identified by u.v. spectrum.

Table 8. Total fatty acid composition of plasma membranes from the yeast and mycelial forms

$\begin{array}{ccc}\text { Fatty acid } & \text { Yeast form* }(\%) & \text { Mycelial form* }(\%) \\ \mathrm{C}_{16: 0} & 19 \cdot 0 \pm 4 \cdot 0 & 24 \cdot 0 \pm 0 \cdot 5 \\ \mathrm{C}_{16: 1} & 8 \cdot 0 \pm \mathrm{I} \cdot 0 & 16 \cdot 0 \pm \mathrm{I} \cdot 0 \\ \mathrm{C}_{16: 2} & 2 \cdot 0 \pm \mathrm{I} \cdot 0 & \text { Trace } \\ \mathrm{C}_{17: 1} & \text { Trace } & 2 \cdot 0( \pm 0 \cdot 0) \\ \mathrm{C}_{18: 0} & 5 \cdot 0 \pm \mathrm{I} \cdot 0 & 7 \cdot 0( \pm 0 \cdot 0) \\ \mathrm{C}_{18: 1} & 26 \cdot 0 \pm 3 \cdot 0 & 26 \cdot 0( \pm 0 \cdot 0) \\ \mathrm{C}_{18: 2} & 30 \cdot 0 \pm 3 \cdot 0 & 18 \cdot 0 \pm \mathrm{I} \cdot 0 \\ \mathrm{C}_{18: 3} & 8 \cdot 0 \pm 3 \cdot 0 & 6 \cdot 0 \pm \mathrm{I} \cdot 0 \\ & * \text { See text. } & \end{array}$

\section{Gas-liquid chromatography}

Fatty acids. The total fatty acid composition of lipid extracts from yeast- and mycelialform plasma membranes is given in Table 8. Identification of those fatty acids for which no standard was available was carried out by plotting log retention time of standards against carbon number (James \& Martin, 1952) which gives a straight line for homologous series.

Sterols. The free sterol compositions of yeast- and mycelial-form plasma membranes are shown in Table 6. Standards were only available in the case of squalene, calciferol, zymosterol and ergosterol. Some minor components, corresponding to breakdown products of ergosterol, could also be positively identified from their occurrence in solutions of ergosterol which had been allowed to stand at room temperature for periods of up to one week. The other sterols were assumed to be intermediates in ergosterol biosynthesis (Barton, Corrie, Marshall \& Widdowson, I973), and by using the data of Vandenheuval \& Court (I968) it was possible to calculate the retention times of these components. By expressing these retention times relative to ergosterol, it was possible to identify tentatively the other sterols found in the free-sterol and sterol-ester fractions. In Tables 6 and 7 calculated relative retention times are shown in parentheses, together with the observed values.

The sterols found in the sterol ester fraction are shown in Table 7. Again, tentative identifications of unknown components have been based on relative retention time data. 24,28-Dehydroergosterol was identified by its u.v. spectrum in both sterol and sterol ester 
Table 9. Amino and neutral sugar composition of yeast- and mycelial-form plasma membranes

$\begin{array}{cccc} & \begin{array}{c}\text { Component or relative } \\ \text { retention time* }\end{array} & \text { Yeast form } \dagger(\%) & \text { Mycelial form } \dagger(\%) \\ \text { Amino sugars } & 0 \cdot 867 & 35 \cdot 0 \pm 2 \cdot 0 & 36 \cdot 0 \pm \mathrm{r} \cdot 0 \\ \text { Neutral sugars } & \text { Glucosamine } & 65 \cdot 0 \pm 2 \cdot 0 & 64 \cdot 0 \pm \mathrm{I} \cdot 0 \\ & 0 \cdot 765 & 6 \cdot 0 \pm \mathrm{r} \cdot 0 & 8 \cdot 0 \pm 4 \cdot 0 \\ & 0 \cdot 777 & 20 \cdot 0 \pm 2 \cdot 0 & 10 \cdot 0( \pm 0 \cdot 0) \\ & \text { Mannose } & 18 \cdot 0( \pm 0 \cdot 0) & 20 \cdot 0( \pm 0 \cdot 0) \\ & \text { Glucose } & 55 \cdot 0( \pm 0 \%) & 63 \cdot 0( \pm 0 \cdot 0) \\ & * \text { Relative to inositol }=\mathrm{I} \cdot 000 . & \\ & \dagger \text { See text. }\end{array}$

Table I0. Amino acid composition of yeast-and mycelial-form plasma membranes

\begin{tabular}{|c|c|c|}
\hline Amino acid & $\begin{array}{l}\text { Yeast form } \\
(\mathrm{mol} \mathrm{\%})\end{array}$ & $\begin{array}{l}\text { Mycelial form } \\
(\mathrm{mol} \%)\end{array}$ \\
\hline Alanine & $8 \cdot 4 \pm 0 \cdot 1$ & $8 \cdot 8 \pm 0 \cdot 2$ \\
\hline Arginine & $3.8 \pm 0.1$ & $3 \cdot 8 \pm 0 \cdot 3$ \\
\hline Aspartic acid & II. $3 \pm 0.2$ & $10.6 \pm 0.1$ \\
\hline Glutamic acid & $9.4 \pm 0.5$ & $10.0( \pm 0.0)$ \\
\hline Glycine & $7.5 \pm 0.1$ & $7.6( \pm 0.0)$ \\
\hline Histidine & $2 \cdot 5 \pm 0 \cdot I$ & $\mathrm{I} \cdot 8 \pm 0.4$ \\
\hline Isoleucine & $4 \cdot 6 \pm 0 \cdot 1$ & $5 \cdot 1 \pm 0 \cdot I$ \\
\hline Leucine & $9 \cdot 4( \pm 0 \cdot 0)$ & $9 \cdot 2( \pm 0 \cdot 0)$ \\
\hline Lysine & $9 \cdot 3 \pm 0 \cdot 6$ & $10.9 \pm 0.1$ \\
\hline Methionine & $0.6 \pm 0.3$ & $0.3( \pm 0.0)$ \\
\hline Phenylalanine & $4 \cdot 3( \pm 0.0)$ & $4 \cdot 3 \pm 0 \cdot 2$ \\
\hline Proline & $5.9 \pm 0.6$ & $5 \cdot 5 \pm 1 \cdot 0$ \\
\hline Serine & $8 \cdot 4 \pm 0.1$ & $8 \cdot 2 \pm 0 \cdot I$ \\
\hline Threonine & $6.4( \pm 0.0)$ & $6 \cdot 3 \pm 0 \cdot 1$ \\
\hline Tryptophan & $0.7 \pm 0.2$ & $0.4( \pm 0.0)$ \\
\hline Tyrosine & $2.8( \pm 0.0)$ & $3 \cdot 3 \pm 0.1$ \\
\hline Valine & $4.7( \pm 0.0)$ & $5 \cdot I \pm 0.1$ \\
\hline
\end{tabular}

fractions. No figures were available to calculate the relative retention time of this sterol. As no known intermediate has a calculated relative retention time of $\mathbf{I} \cdot 087$, it is possible that this component was 24,28 -dehydroergosterol.

Sugars. Carbohydrate in the form of hexosamines made up approximately $3.0 \%$ of the dry weight of yeast-form plasma membranes and $6.5 \%$ of mycelial-form membranes. The major component indicated by g.l.c. was glucosamine (Table 9) although under the hydrolysis conditions used this could originally have been present as $N$-acetyl glucosamine. Table 9 shows that the major neutral sugars were glucose and mannose. Minor unidentified components were found in both amino and neutral sugar fractions.

\section{Amino acid analyses}

The results of the amino acid analyses of the two types of plasma membranes are given in Table Io. The presence of mercaptoethanol in the hydrolysis mixture prevented the destruction of methionine. It can be seen that all amino acids were present and that some slight differences between yeast- and mycelial-form membranes were observable. 


\section{DISCUSSION}

The media described for the production of the yeast and mycelial form of Candida albicans 6406 are satisfactory in that they are entirely synthetic and high yields of the organism are produced.

Previous reports of plasma membrane fractionation from yeasts have contained little information on the purity of the preparation. Garcia-Mendoza \& Villanueva (1967), working with lysed protoplasts from Candida utilis, used a fraction sedimenting between 1500 and I5000 $\mathrm{g}$ as their plasma membrane preparation, their only criterion for purity being the appearance of negatively stained material in the electron microscope. Longley et al. (1968), using lysed protoplasts from Saccharomyces cerevisiae, sedimented their plasma membranes at $1500 \mathrm{~g}$ and used the absence of nucleic acid as a criterion for purity. Nurminen et al. (1970), using a different technique to isolate this component from $S$. cerevisiae, mention the presence of $\mathrm{Mg}^{2+}$ dependent ATPase and absence of NADH oxidase as evidence for purity. However, recent work by Dubé et al. (1973) has thrown doubt on the original isolation procedure used by Nurminen et al. (1970). Matile et al. (1967) used the presence of an oligomycin resistant, $\mathrm{Na}^{+} / \mathrm{K}^{+}$stimulated, $\mathrm{Mg}^{2+}$ dependent ATPase as a marker enzyme in isolating a plasma membrane preparation from $S$. cerevisiae. It is dangerous to assume that certain enzymes occur (or do not occur) in the plasma membrane of yeasts and then base an isolation procedure on these assumptions.

The use of specific reagents for labelling plasma membranes from other sources is now well documented (Bretscher, I973a). Schibeci et al. (I973a) used various radioactive compounds to label intact protoplasts from $S$. cerevisiae and followed the distribution of radioactivity upon subsequent fractionation. These authors, however, present evidence that their preparation contained substantial contamination from other components and their analytical data failed to account for more than $30 \%$ of the dry weight of the plasma membrane fraction. A second paper by these workers (Schibeci, Rattray \& Kidby, I $973 b$ ) has demonstrated that the radioactive labels used in this present study are specific for the plasma membrane of yeasts, as judged by autoradiographic evidence. Thus, the data provided here are indicative of preparations of plasma membranes from the two morphological forms of C. albicans which were devoid of extensive contamination from other cytoplasmic membranes. Besides distribution of radioactive label and protein after recentrifugation, further evidence for purity includes lack of succinic dehydrogenase activity, indicating the absence of mitochondrial contamination, and lack of obvious contamination when the preparations were observed under the electron microscope.

The reproducibility of the analytical data from three preparations of plasma membranes from the yeast and mycelial forms of $C$. albicans is additional evidence for the homogeneity of these fractions. The total nucleic acid content of both yeast and mycelial plasma membranes was very low, which together with other data (vide supra) suggests that there was little or no contamination with cytoplasmic constituents.

One major difference between the yeast and mycelial forms was an increased carbohydrate content of membranes from the latter. This result is in agreement with the finding that protoplasts from the mycelial form were labelled with optical brighteners such as Tinopal BOPT, whilst those from the yeast form were not. This material could arise from three possible sources: (i) wall material non-specifically reabsorbed on to the protoplast surface; (ii) undigested wall; (iii) wall so firmly attached that it is possible to regard it as an integral part of the membrane-such wall/plasma-membrane attachment sites could represent growing points or sites of wall synthesis. 
The mode of protoplast release from the mycelial form (Fig. $2 e$ ) would appear to rule out (iii). However, further carbohydrate analysis seems to favour either (ii) or (iii). Thus Chattaway et al. (1968) have shown that in a variety of growth media the walls of the yeast and mycelial forms of $C$. albicans have a remarkably constant composition. The glucose: mannose ratios for the two forms were $\mathrm{I} \cdot 3$ and $\mathrm{I} \cdot 7(\mathrm{w} / \mathrm{w})$ respectively. In the case of plasma membranes, this ratio was 3.0 for membranes derived from the yeast form and 3.5 for membranes from the mycelial form. This finding eliminates possibility (i), which would predict glucose: mannose ratios similar to the wall values. Lampen (1968) has proposed that the yeast wall is composed of two major layers, the inner one mainly glucan and the outer one mannan and mannan-protein. Thus, the increase in the proportion of glucose present, if it were derived from (ii) or (iii), would agree with Lampen's model. It is difficult to resolve absolutely these two possibilities. Previous reports of the carbohydrate content of yeast membranes have varied from 4 to $30 \%$ (Matile, 1970) and recent work by Nombela, Uruburu \& Villanueva (1974) has indicated that plasma membranes from the mycelial fungus Fusarium culmorum also have a high (30\%) carbohydrate content.

Differences in the lipid composition of the two types of plasma membrane are apparent. Mycelial plasma membranes contain significantly less sterol, both free and esterified, and proportionately more triglyceride and free fatty acids. These differences do not affect the sensitivity of the yeast and mycelial forms to polyene antibiotics; they were equally sensitive to nystatin (minimum growth-inhibitory concentration I $\mu \mathrm{g}$ nystatin/ml). The major phospholipid from yeast plasma membranes is phosphatidyl ethanolamine, with only small amounts of phosphatidyl choline being present. However, in mycelial plasma membranes, these two phospholipids appear in approximately equal amounts and are the only ones present.

Ergosterol is the main free sterol from both the yeast- and mycelial-form plasma membranes, whilst the relative amounts of other precursors differ between the two forms. However, the major esterified sterol appears to be zymosterol, with only small amounts of esterified ergosterol. It is not known if esterified zymosterol is acting as a precursor of ergosterol in the plasma membrane or is an end product. Dr T. Y. Koh (personal communication) has found that the sterol-ester composition of walls from the yeast form of $C$. albicans closely follows that from yeast-form plasma membranes. It is possible, therefore, that esterified sterols are being exported to the wall. Investigations are being carried out to test this hypothesis as well as to examine, in detail, differences in the enzymic composition of plasma membranes from the two forms of the organism.

This work was financed by the Medical Research Council. The assistance of Dr D. Kerridge in the preparation of the manuscript, Mrs K. M. Marriott with the electron microscopy and Mr G. K. Parr with the amino acid analyses was greatly appreciated.

\section{REFERENCES}

Anderson, F. B. \& Millbank, J. W. (I966). Protoplast formation and yeast cell wall structure. Biochemical Journal 99, 682-687.

Baird, J. K. \& CUNNingham, W. L. (I97I). Formation of yeast protoplasts by using an enzyme preparation from Cytophaga. Biochemical Journal 125, 32P-33P.

Barton, D. H. R., Corrie, J. E. T., Marshall, P. J. \& Widdowson, D. A. (I973). Biosynthesis of terpenes and steroids. VII. Unified scheme for the biosynthesis of ergosterol in Saccharomyces cerevisiae. Bioorganic Chemistry 2, 363-373. 
BittMAN, R. \& FisChKoFf, S. A. (1972). Fluorescence studies of the binding of the polyene antibiotics filipin III, amphotericin B, nystatin and lagosin to cholesterol. Proceedings of the National Academy of Sciences of the United States of America 69, 3795-3799.

Boulton, A. A. \& EDDY, A. A. (1962). The properties of certain particles isolated from yeast protoplasts disrupted by osmotic shock. Biochemical Journal 82, I6P-17P.

BreiviK, O. N. \& OwADEs, J. L. (I957). A semi-micro method for the determination of the percentages of ergosterol and 24,28 dehydro-ergosterol in yeast fat. Journal of Agricultural and Food Chemistry 5, 360-363.

BRETSCHER, M. S. (1973a). Membrane structure: some general principles. Science, New York 18I, 622-629

BRETSCHER, M. S. (1973b). On labelling membranes. Nature New Biology 245, II6-II 7 .

Brown, J. P. \& Perham, R. N. (1973). A highly sensitive method for amino acid analysis by double-isotope-. labelling technique using dansyl chloride. European Journal of Biochemistry 39, 69-73.

Chattaway, F. W., Holmes, M. R. \& Barlow, A. J. E. (1968). Cell wall composition of the mycelial and blastospore forms of Candida albicans. Journal of General Microbiology 51, 367-376.

Chen, P. S., Toribara, T. Y. \& Warner, H. (1956). Microdetermination of phosphorus. Analytical Chemistry 28, $1756-1758$.

Crane, F. L., MiI, S., Hauge, J. G., Green, D. E. \& Beinert, H. (1956). On the mechanism of dehydrogenation of fatty acyl derivatives of coenzyme A. I. The general fatty acyl coenzyme A dehydrogenase. Journal of Biological Chemistry 218, 70I-716.

DitTMER, J. C. \& Lester, R. L. (1964). A simple, specific spray for the detection of phospholipids on thin layer chromatograms. Journal of Lipid Research 5, 126-127.

Drabikowski, W., Lagwinska, E. \& Sarzala, M. G. (1973). Filipin as a fluorescent probe for the location of cholesterol in the membranes of fragmented sarcoplasmic reticulum. Biochimica et biophysica acta 291, $6 \mathrm{I}-70$.

DubÉ, J., Setterfield, G., Kiss, G. \& Lusena, C. V. (I973). Fate of the plasma-membrane of Saccharomyces cerevisiae during cell rupture. Canadian Journal of Microbiology 19, 285-290.

Elorza, M. V., Munoz-Ruiz, E. \& Villanueva, J. R. (I966). Production of yeast cell wall lytic enzymes on a semi-defined medium by a Streptomyces. Nature, London 210, 442-443.

ExLEY, D. (I957). The determination of I0-100 ng quantities of hexosamine. Biochemical Journal 67, 52-60.

Folch, J., Lees, M. \& Sloane-Stanley, G. H. (1957). A simple method for the isolation and purification of total lipids from animal tissues. Journal of Biological Chemistry 226, 497-509.

Garcia-Mendoza, C. \& Villanueva, J. R. (I962). Production of yeast protoplasts by an enzyme preparation of Streptomyces species. Nature, London 195, 1326-1327.

Garcia-Mendoza, C. \& Villanueva, J. R. (1967). Preparation and composition of the protoplast membrane of Candida utilis. Biochimica et biophysica acta 136, 189-195.

GHuYSen, J.-M., Tipper, D. J. \& Strominger, J. L. (I966). Enzymes that degrade bacterial cell walls. In Methods in Enzymology, vol. 8, pp. 685-699. Edited by E. F. Neufeld and K. Ginsburg. New York and London: Academic Press.

Green, D. E., MiI, S. \& KoHout, P. M. (I955). Studies on the terminal electron transport system. I. Succinic dehydrogenase. Journal of Biological Chemistry 217, 55I-567.

Gull, K., MOORE, P. M. \& TRINCI, A. P. J. (1972). Formation of protoplasts from Geotrichum lactis and use of the fluorescence to detect cell walls. Transactions of the British Mycological Society 59, 79-85.

HeINEN, W. \& DE VRIES, H. (I966). A combined micro and semi-micro colorimetric determination of long chain fatty acids from plant cutin. Archiv für Mikrobiologie 54, 339-349.

JAMES, A. T. \& MARTIN, A. J. P. (1952). Gas-liquid partition chromatography: the separation and microestimation of volatile fatty acids from formic to dodecanoic acid. Biochemical Journal 5o, 679-69o.

Kassai, M., Podleski, T. R. \& Changeux, J. P. (1970). Some structural properties of excitable membranes labelled by fluorescent probes. FEBS Letters $7, \mathrm{I}_{3}-\mathrm{I} 9$.

Kobayashi, G. S., Friedman, L. \& Kofroth, J. F. (I964). Some cytological and pathogenic properties of spheroplasts of Candida albicans. Journal of Bacteriology 88, 795-80I.

LAMPEN, J. O. (1968). External enzymes of yeast: their nature and formation. Antonie van Leeuwenhoek 34, I-I8.

Lampen, J. O., Arnow, P., Borowska, Z. \& LASKin, A. I. (1962). Location and role of sterol at nystatin binding sites. Journal of Bacteriology 84, I I 52-I I60.

LONGLEY, R. P., Rose, A. H. \& KNIGHTS, B. A. (I968). Composition of the protoplast membrane of Saccharomyces cerevisiae. Biochemical Journal 108, 40I-4I 2. 
Lowry, O. H., Rosebrough, N. J., Farr, A. L. \& Randall, R. J. (I95I). Protein measurement with the Folin phenol reagent. Journal of Biological Chemistry 193, 265-275.

Mardon, D. N., Balish, E. \& Phillips, A. W. (1969). Control of dimorphism in a biochemical variant of Candida albicans. Journal of Bacteriology 100, 701-707.

Mardon, D. N., Hurst, S. K. \& Balish, E. (197I). Germ tube production by Candida albicans in minimal culture media (liquid). Canadian Journal of Microbiology 17, 85I-856.

Matile, P. (1970). Properties of the purified cytoplasmic membrane of yeast. Federation of European Biochemical Societies Symposium 2o, pp. 39-49. Edited by J. R. Villanueva and F. Ponz. New York and London: Academic Press.

Matile, P., Moor, H. \& Mühlethaler, K. (1967). Isolation and properties of plasmalemma in yeast. Archiv für Mikrobiologie 58, 20I-21I.

Nichols, B. W. \& Moorhouse, R. (1969). The separation, structure and metabolism of monogalactosyl diglyceride species in Chlorella vulgaris. Lipids 4, 311-316.

NICKERSON, W. J. \& MANKOWSKI, Z. (1953). Role of nutrition in the maintenance of yeast shape in Candida. American Journal of Botany 40, 584-592.

Nombela, C., Uruburu, F. \& Villanueva, J. R. (1974). Studies on membranes isolated from extracts of Fusarium culmorum. Journal of General Microbiology 81, 247-254.

Nurminen, T., Oura, E. \& Suomalainen, H. (1970). The enzymic composition of the isolated cell wall and plasma-membrane of baker's yeast. Biochemical Journal II6, 6I-69.

Rondle, C. M. \& Morgan, W. T. J. (1955). The determination of glucosamine and galactosamine. Biochemical Journal 6r, 586-589.

Salton, M. R. J., Schor, M. T. \& NG, M. H. (1972). Internal localization of Micrococcus lysodeikticus membrane ATPase by iodination with ${ }^{125}$ I. Biochimica et biophysica acta 290, 408-413.

SchibeCI, A., Rattray, J. B. M. \& Kidby, D. K. (I973a). Isolation and identification of yeast plasmamembrane. Biochimica et biophysica acta 3II, I5-25.

SChibeci, A., RatTray, J. B. M. \& KidBy, D. K. (1973 $b$ ). Electron microscope autoradiography of labelled yeast plasma-membrane. Biochimica et biophysica acta 323, 532-538.

SKIDMORE, W. D. \& ENTENMAN, C. (1962). Two dimensional thin-layer chromatography of rat liver phosphatides. Journal of Lipid Research 3, 47I-475.

Skipski, V. P., Peterson, R. F. \& Barclay, M. (1964). Quantitative analysis of phospholipids by thin-layer chromatography. Biochemical Journal 9o, 374-378.

StARR, P. R. \& PARks, L. W. (1972). Transmethylation of sterols in aerobically adapting Saccharomyces cerevisiae. Journal of Bacteriology 109, 236-242.

Sweeley, C. C., Bentley, R., Makita, M. \& Wells, W. W. (1963). Gas-liquid chromatography of trimethylsilyl derivatives of sugars and related substances. Journal of the American Chemical Society 85, 2497-2507.

Tkacz, J. S., Cybulska, E. B. \& Lampen, J. O. (I97I). Specific staining of wall mannan in yeast cells with fluorescein conjugated Concanavalin A. Journal of Bacteriology 105, I-5.

Trevelyan, W. E. \& Harrison, J. S. (1952). Fractionation and microdetermination of cell carbohydrates. Biochemical Journal 5o, 298-305.

VANDENheuval, F. A. \& CourT, A. S. (1968). Reference high efficiency non polar packed columns for the gas-liquid chromatography of nanogram amounts of steroids. I. Retention time data. Journal of Chromatography 38, 439-459.

VAN HANDel, E. \& ZiLVERSMit, D. B. (1957). Micromethod for the determination of serum triglycerides. Journal of Laboratory and Clinical Medicine 5o, i 52-I 57.

WIDRA, A. (I964). The influence of the dextrose/phosphate ratio, nitrogen source and various cations on filamentation in Candida albicans. Mycopathologia et mycologia applicata 23, 197-202.

Wood, P., Imaichi, K., Knowles, J., Michaels, C. \& Kinsell, L. (1964). The lipid composition of human plasma chylomicrons. Journal of Lipid Research 5, 225-23I. 